\title{
The anti-parasitic effect of probiotic bacteria via limiting the fecundity of Trichinella spiralis female adults
}

\author{
B. BUCKOVÁ 1 , Z. HURNÍKOVÁ1, A. LAUKOVÁ ${ }^{2}$, V. REVAJOVÁ ${ }^{3}$, E. DVOROŽŇÁKOVÁ1*
}

\begin{abstract}
${ }^{1}$ Institute of Parasitology, Slovak Academy of Sciences, Hlinkova 3, 04001 Košice, Slovakia, ${ }^{*}$-mail: dvoroz@saske.sk; ${ }^{2}$ Institute of Animal Physiology - Centre of Biosciences, Slovak Academy of Sciences, Šoltésovej 4, 04001 Košice, Slovakia; ${ }^{3}$ University of Veterinary Medicine and Pharmacy in Košice, Komenského 73, 04181 Košice, Slovakia
\end{abstract}

\section{Article info}

Received January 11, 2018 Accepted March 14, 2018

\begin{abstract}
Summary
A potential protective effect of probiotic strains against zoonotic Trichinella spiralis infection was investigated in the framework of a new therapeutic strategy aimed at using probiotics to control parasitic zoonoses. The study was focused on the impact of six selected probiotic (bacteriocinogenic) strains on the intensity of $T$. spiralis infection and female fecundity ex vivo and in vitro. Bacterial strains of different origin (Enterococcus faecium EF55, Enterococcus faecium $2019=$ CCM7420, Enterococcus faecium AL41 = CCM8558, Enterococcus durans ED26E/7, Lactobacillus fermentum AD1 = CCM7421, Lactobacillus plantarum 17L/1) were administered daily in a dose of $10^{9} \mathrm{CFU} / \mathrm{ml}$ in $100 \mu \mathrm{l}$, and mice were infected with $400 \mathrm{~T}$. spiralis larvae on day 7 of treatment. Female adults of $T$. spiralis were isolated on day 5 post infection (p.i.) and subsequently were used in fecundity test ex vivo. E. faecium CCM8558, E. faecium CCM7420 and E. durans ED26E/7 strains significantly reduced the number of adults in the intestine. The application of $L$. fermentum CCM7421, L. plantarum $17 \mathrm{~L} / 1, E$. faecium CCM8558 and $E$. durans ED26E/7 caused a significant decrease in the number of muscle larvae. The treatment with E. faecium CCM8558 and E. durans ED26E/7 showed the highest inhibitory effect on female fecundity (94\%). The number of newborn larvae (NBL) was also significantly decreased after administration of $L$. fermentum CCM7421 and L. plantarum 17L/1 (80 \%). A direct impact of probiotic strains on female reproductive capacity was examined in vitro in females isolated from untreated infected mice on day 5 p.i. A correlation was found between the inhibitory effect and the concentration of probiotic strains. The reduction effects of the strains manifested as follows: L. fermentum CCM7421 (93 \%), E. faecium CCM8558, L. plantarum 17L/1, E. faecium EF55 (about 80 \%), E. faecium CCM7420 and E. durans ED26E/7 (about $60 \%$ ).
\end{abstract}

Keywords: Trichinella spiralis; female fecundity; probiotic bacteria; Enterococcus; Lactobacillus

\section{Introduction}

The host gut represents a complex ecosystem where the interactions between intestinal microbiota, immune system, and pathogens occur. For healthy organisms is crucial to form the balance between the gut microbiota and the host organism (Berrilli et al., 2012). It has been recognized that the excretory/secretory molecules produced by helminths may lead to significant alterations in the composition of the gut microbiota (Walk et al., 2010; Li et al., 2012). Gut microbiota products and metabolites also significantly influence the survival and the physiology of many parasites and, consequently, the outcome of parasitic infections. This suggests that probiotic bacteria can successfully reduce the pathogenicity of many parasites, probably through multiple mechanisms (Berrilli et al., 2012; Travers et al.,

\footnotetext{
$\overline{\text { * - corresponding author }}$
} 
2011). The main mechanisms of probiotic actions include: enhancement of the gut epithelial barrier, increase of adhesion to intestinal mucosa and simultaneous inhibition of pathogen adhesion, competitive elimination of pathogens, production of anti-microbial molecules, and modulation of the immune system (Goudarzi et al., 2014). Several studies have investigated the ability of probiotics to influence the course of different parasitic infections (Travers et al., 2011). Positive effects of probiotic bacteria reducing the parasite burden and pathological changes in experimental trichinellosis due to the activation of local and systematic immune responses were previously described (Bautista-Garfias et al., 1999, 2001; Martínez-Gómez et al., 2009, 2011; El Temsahy et al., 2015; Dvorožňáková et al., 2016), in ascariasis (Solano-Aguilar et al., 2004), and toxocarosis (Basualdo et al., 2007). Probiotic bacterial strains can positively affect protozoan parasitic infections such as cryptosporidiosis, giardiasis, coccidiosis (Gargala, 2008; Alak et al., 1999; Pérez et al., 2001; Shukla and Sidhu, 2011). Probiotic bacterial strains are also being tested in the host protection against blood parasites like Babesia, Plasmodium, and Trypanosoma (Bautista-Garfias et al., 2005; Galdeano and Perdigón, 2006; Martínez-Gómez et al., 2006; Eze et al., 2012).

Trichinellosis is a serious food-borne parasitic zoonosis caused by the nematode of the genus Trichinella, which is characterized by an extremely wide host range and worldwide distribution (Bruschi, 2012; Goździk et al., 2017). In general, therapeutic approaches against trichinellosis can be divided into two groups: classic and alternative. The classic treatment includes the application of anthelmintics, primarily albendazole and mebendazole (Gottstein et al., 2009); however, the efficacy of these benzimidazole derivatives is limited by the following factors: 1) weak activity against encapsulated larvae, 2) low water solubility, 3) increasing anthelmintic resistance, 4) contraindication in children and pregnancy (Yadav and Temjenmongla, 2012). Therefore, the anti-parasitic potential of probiotic bacteria (El Temsahy et al., 2015), natural proteins (Othman et al., 2016), and substances such as myrrh, thyme or artemisinin (Attia et al., 2015; Abou Rayia et al., 2017) is being increasingly utilized in recent years.

The present study was designed to study the anti-parasitic effects of six different probiotic strains of lactobacilli and enterococci on the parasite burden in the host and on the fecundity of $T$. spiralis females.

\section{Materials and Methods}

\section{Probiotic strains}

The effects of the following bacteria were tested: bacteriocin-producing strains with probiotic properties (Enterococcus faecium EF55, Enterococcus faecium 2019 = CCM7420, Enterococcus faecium AL41 = CCM8558, Enterococcus durans ED26E/7, and Lactobacillus plantarum 17L/1) and probiotic strain Lactobacillus fermentum AD1 = CCM7421. All used strains are original isolates which were not previously used for this purpose.
Enterococcus faecium EF55 was isolated from the chicken crop and characterized at the Institute of Animal Physiology SAS - IAP SAS, Košice, Slovakia. The strain produces a thermo-stable bacteriocin EF55 (Strompfová et al., 2010).

Enterococcus faecium $2019=\mathrm{CCM} 7420$ is a rabbit-derived strain with probiotic properties, which produces enterocin 2019 (Ent 2019) (Pogány Simonová et al., 2013). It was isolated and characterized at IAP SAS, Košice, Slovakia and deposited in the Czech Culture Collection of Microorganisms, Brno, Czech Republic CCM7420.

Enterococcus faecium AL41 = CCM8558 (isolated and characterized at IAP SAS, Košice, Slovakia and deposited in the Czech Culture Collection of Microorganisms, Brno, Czech Republic CCM8558) is an environment-derived strain. The strain produces an enterocin $\mathrm{M}$ with a wide antimicrobial inhibitory spectrum and possesses probiotic properties (Lauková et al., 2012; Mareková et al., 2007).

Enterococcus durans ED26E/7 was isolated from traditional ewes milk lump cheese at the Research Dairy Institute, Žilina - RDI, Žilina, Slovakia; but identified, characterized and prepared for experiment at IAP SAS, Košice, Slovakia (Lauková et al., 2015).

Lactobacillus plantarum 17L/1 was isolated from stored ewes cheese (RDI, Žilina, Slovakia) but identified, characterized and prepared for experiment at IAP SAS, Košice, Slovakia (Lauková et al., 2013).

Lactobacillus fermentum AD1 = CCM7421 was isolated and characterized at IAP SAS, Košice, Slovakia and deposited in the Czech Culture Collection of Microorganisms, Brno, Czech Republic - CCM7421. It is a canine-derived strain possessing probiotic properties (Strompfová et al., 2008).

All used strains were evaluated according to the EFSA rules (Piskoríková, 2010). For the experiment they were prepared as follows: they were cultivated in MRS broth (Merck, Eppelheim, Germany) at $37^{\circ} \mathrm{C}$ for $24 \mathrm{~h}$. Broth cultures were centrifuged (30 min at 10,000g) and the sediment was resuspended in Ringer solution (Merck, pH 7.0) to a concentration of $10^{9}$ colony forming units per $\mathrm{ml}(\mathrm{CFU} / \mathrm{ml})$. The purity of the strains was checked by the standard microbiological method (ISO-International Organization for Standardization) by spreading dilutions in Ringer solution (Merck, pH 7.0) onto the selective medium ME-Enterococcus agar (ISO-15214, Difco, Detroit, USA) and/or MRS agar (Merck, Eppelheim, Germany). The cultures for application were stored at $4{ }^{\circ} \mathrm{C}$.

\section{Parasite}

The reference isolate of Trichinella spiralis (ISS 004) (obtained and assigned codes from the Trichinella Reference Centre in Rome), maintained by serial passages in ICR mice at the Institute of Parasitology SAS, was used for the infection. Larvae were released by artificial digestion $\left(1 \%\right.$ pepsin, $1 \% \mathrm{HCl}$ for $4 \mathrm{~h}$ at $37^{\circ} \mathrm{C}$; both from Sigma-Aldrich, Germany) of tissue following the protocol of Kapel and Gamble (2000) and kept in saline solution until inoculation of experimental mice. 


\section{Experimental design}

The experiment was performed on pathogen-free eight week old male BALB/c mice (VELAZ, Prague, Czech Republic; $n=110$ ) weighting $18-20 \mathrm{~g}$. Mice were kept under a 12-h light/dark regime at room temperature $\left(22-24{ }^{\circ} \mathrm{C}\right)$ and $56 \%$ humidity on a commercial diet and water.

Animals were divided randomly into 7 groups: Control $(n=15)-$ $T$. spiralis infection without the administration of bacterial strains; Group $1(n=15)-$ Enterococcus faecium EF55 + T. spiralis; Group $2(n=15)-E$. faecium CCM7420 + T. spiralis; Group $3(n=15)$ - E. faecium CCM8558 + T. spiralis; Group $4(n=15)-E$. durans ED26E/7 + T. spiralis; Group $5(n=15)$ - Lactobacillus fermentum CCM7421 + T. spiralis; Group $6(n=15)-L$. plantarum 17L/1 $+T$. spiralis. Probiotic strains were administered per os daily at a dose of $10^{9} \mathrm{CFU} / \mathrm{ml}$ in $100 \mu \mathrm{l}$ and mice were infected per os with $400 T$. spiralis larvae/mouse on day 7 of treatment. Samples of the small intestine and muscles were obtained on days: 5, 11, 18, 25 and 32 p.i. For ex vivo fecundity test, adult $T$. spiralis females were isolated from the small intestine of three mice from each group on day 5 p.i.

In vitro fecundity test included mice $(\mathrm{n}=5)$ without probiotic treatment and infected per os with $400 \mathrm{~T}$. spiralis larvae/mouse. Similarly, female adults of $T$. spiralis were obtained from the small intestine on day 5 p.i.

\section{Intestinal worm burdens}

The intestinal phase of infection was investigated on days 5, 11 and 18 p.i. The small intestine was cut into $5-10 \mathrm{~cm}$ long pieces, placed into a sieve and incubated in conical pilsner glasses in $37{ }^{\circ} \mathrm{C} \mathrm{NaCl}$ ( $0.9 \%$ saline) overnight. After incubation, gut pieces were discarded and the worms in the sediment were counted under stereomicroscope at $60 \mathrm{x}$ magnification (Leica S8APO, Leica Microsystems, Germany).

\section{Isolation of muscle larvae}

The muscle phase of infection was examined on day 18, 25 and 32 p.i. Whole eviscerated carcasses were minced and artificially digested $\left(1 \%\right.$ pepsin $\mathrm{HCl}$ for $4 \mathrm{~h}$ at $37^{\circ} \mathrm{C}$; both from Sigma-Aldrich, Germany), according to Kapel and Gamble (2000). Samples were allowed to settle for 20 min before the supernatant was discarded and the sediment was poured through a $180 \mu \mathrm{m}$ sieve into a conical glass and washed with tap water. The sediment was finally transferred to a gridded Petri dish and counted using a stereomicroscope at $40 \mathrm{x}$ magnification (Leica S8APO, Leica Microsystems, Germany). Depending on the density of larvae either a sub-sample or the whole sample was counted.

\section{Obtaining of female adults for fecundity tests}

The adult $T$. spiralis females were obtained according to Cabaj (1990). The small intestine was washed with PBS medium $(\mathrm{pH}$ 7.2), split longitudinally, cut into $1 \mathrm{~cm}$ long pieces, placed into a sieve over $50 \mathrm{ml}$ beakers containing RPMl 1640 medium (Sig-
ma-Aldrich, Germany) with antibiotics (100U/ml penicillin; 100U/ml streptomycin) and incubated in a water bath at $37^{\circ} \mathrm{C}$ for $2 \mathrm{~h}$. After incubation, gut pieces were discarded and worms in the medium were centrifuged in centrifuge tubes (Falcon, France) at $67 \mathrm{~g}$ for 5 min. The sediment was finally transferred to a Petri dish and the female worms were identified using a stereomicroscope at $40 \mathrm{x}$ magnification (Leica S8APO, Leica Microsystems, Germany).

\section{Ex vivo fecundity test}

The females isolated from the gut of treated and infected mice (4 from each mouse) were rinsed with the incubation medium, transferred to separate wells of a 24-well tissue culture plate (Falcon, France) containing RPMI 1640 medium (Sigma-Aldrich, Germany) supplemented with $3 \%$ foetal bovine serum plus antibiotics (100U/ml penicillin; $100 \mathrm{U} / \mathrm{ml}$ streptomycin). The plates were sealed with plastic wrap and incubated for $20 \mathrm{~h}$ at $37{ }^{\circ} \mathrm{C}$ in $5 \%$ $\mathrm{CO}_{2}$. NBL were counted in each well using an inverted microscope at $60 \mathrm{x}$ magnification (Leica DM IL LED, Leica Microsystems, Germany). Results were expressed as the average number of NBL per one female parasite.

\section{In vitro fecundity test}

T. spiralis female adults were obtained from the small intestine of untreated infected mice on day 5 p.i. (30 from each mouse) and incubated afterwards in RPMI 1640 medium (Sigma-Aldrich, Germany) enriched with $3 \%$ foetal bovine serum and selected probiotic strain ( $E$. faecium EF55; E. faecium CCM7420; E. faecium CCM8558; E. durans ED26E/7; L. fermentum CCM7421; L. plantarum $17 \mathrm{~L} / 1)$ at different concentration $\left(10^{7}, 10^{5}, 10^{3}\right.$ and $10^{1}$ $\mathrm{CFU} / \mathrm{ml}$ ) or without strains (control) for $20 \mathrm{~h}$ at $37^{\circ} \mathrm{C}$ in $5 \% \mathrm{CO}_{2}$. NBL were counted in each well using an inverted microscope at 60 x magnification (Leica DM IL LED, Leica Microsystems, Germany). Results were expressed as the average number of NBL per one female parasite.

\section{Statistical analysis}

Statistical differences were assessed using one-way ANOVA, followed by post hoc Tukey's test (a value of $P<0.05$ was considered significant), which allowed comparison between each two groups at each time point. The analyses were performed using the Statistica 6.0 (Stat Soft, Tulsa, USA) statistical package.

\section{Ethical Approval and/or Informed Consent}

The research related to animals has been complied with all the relevant national regulations and institutional policies for the care and use of animals. The experimental protocol was in compliance with current Slovak ethical rules for animal handling and it was approved by the Animal Care Committee of the Institute of Parasitology SAS and the State Veterinary and Food Administration of the Slovak Republic (Ro-3184/14-221). 

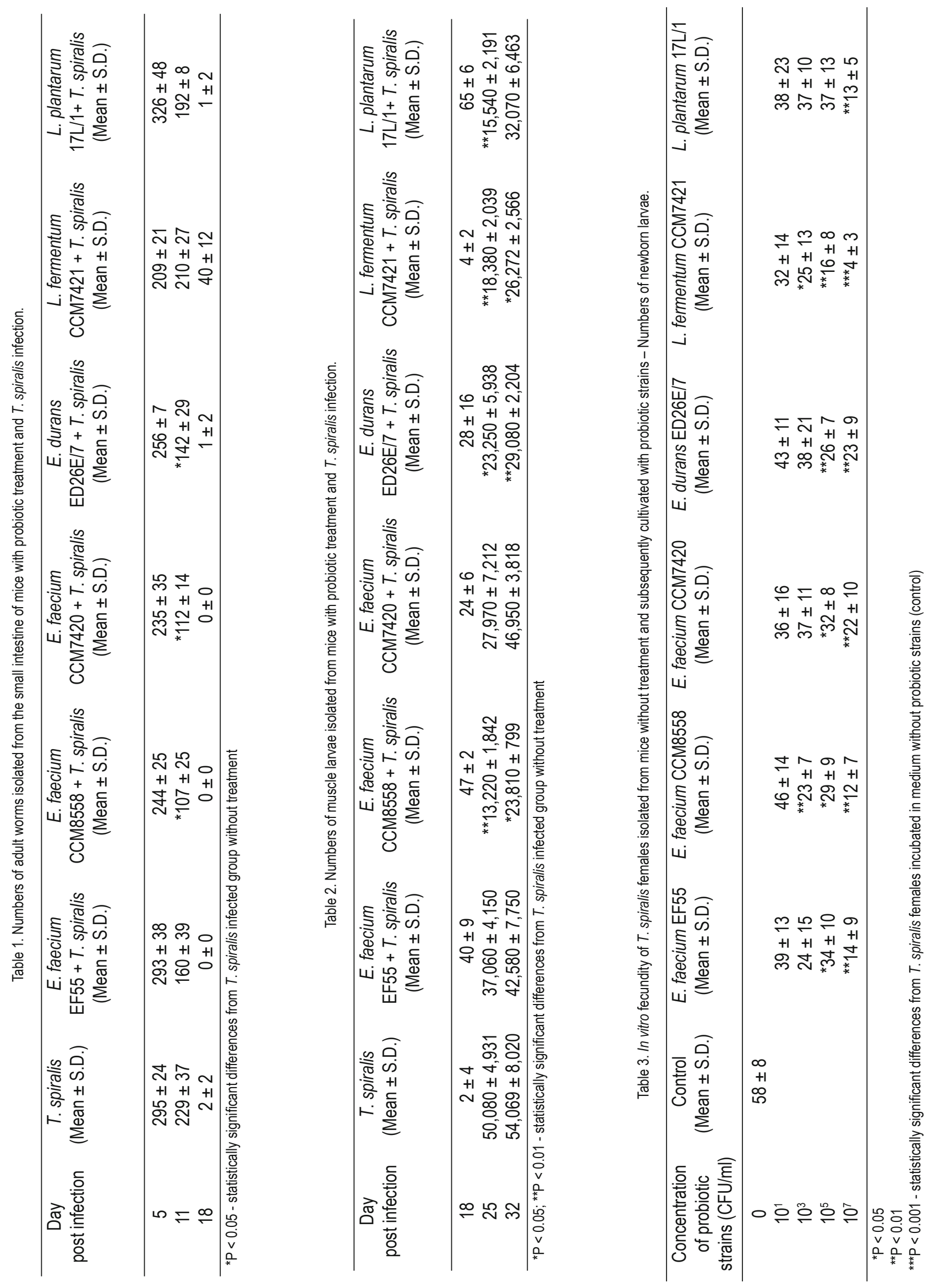


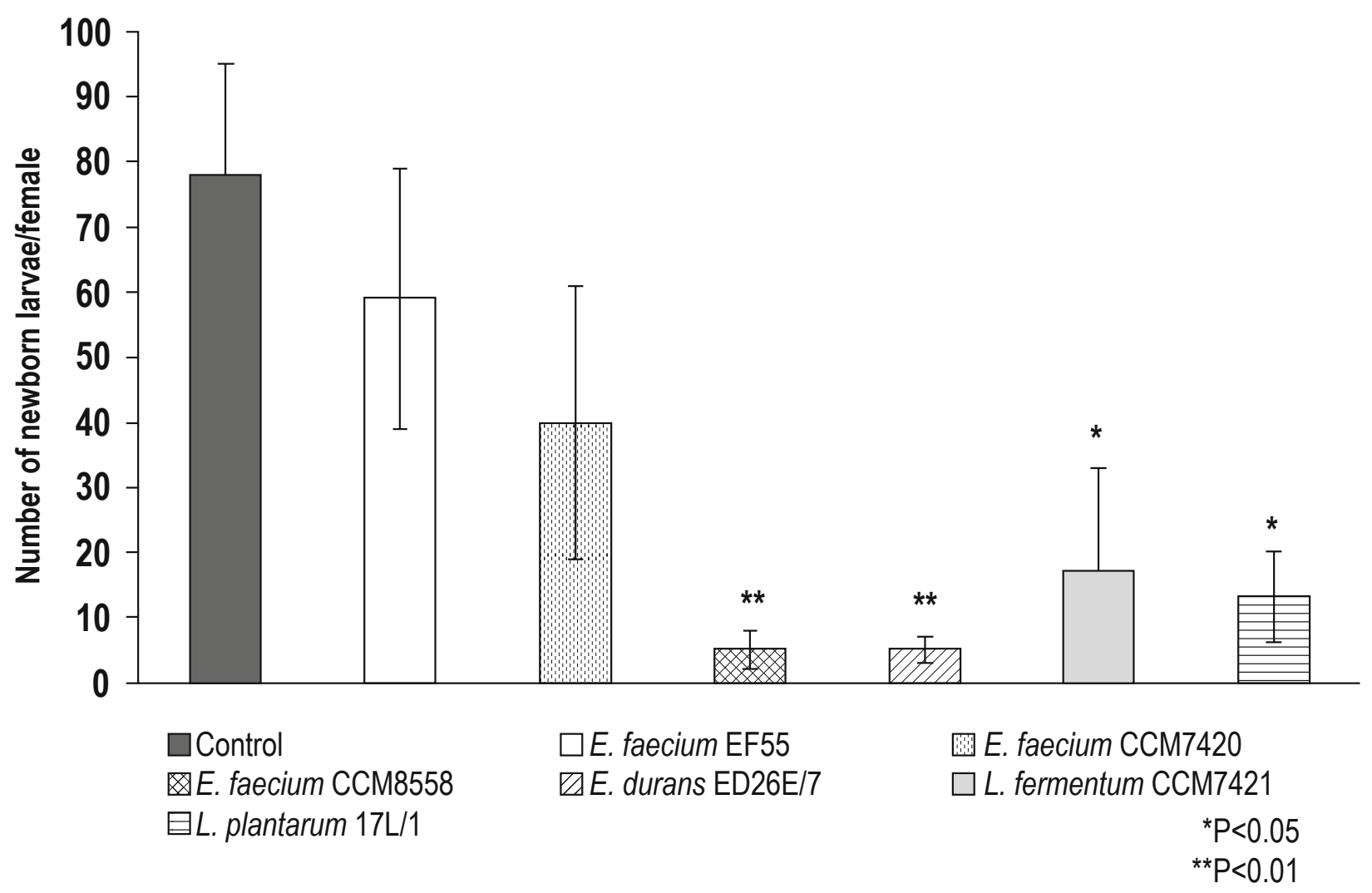

Fig. 1. Ex vivo fecundity of $T$. spiralis females isolated from mice treated with probiotic strains - Numbers of newborn larvae. ${ }^{*} \mathrm{P}<0.05$; ${ }^{*} \mathrm{P}<0.01$-statistically significant differences from $T$. spiralis infected group without probiotic treatment (control).

\section{Results}

Parasite burden - numbers of adults and muscle larvae

The highest numbers of $T$. spiralis adults $(209-326)$ were found in the small intestine on day 5 p.i. in all groups (Table 1). A significant reduction of intestinal parasites occurred on day 11 p.i. in mice with administration of bacteriocin-producing strains $E$. faecium CCM8558 (107 \pm 25$)$, E. faecium CCM7420 (112 \pm 14$)$ and E. durans ED26E/7 (142 \pm 29$)$. Mice with this probiotic treatment absolutely eliminated adults from the small intestine till day 18 p.i. In evaluation of muscle phase of infection (Table 2), the occurrence of $T$. spiralis larvae was sporadic on day 18 p.i. $(2-65)$. Numbers of muscle larvae reached the maximum in untreated mice on day 25 and 32 p.i. $(50,080 \pm 4,931$ and $54,069 \pm 8,020$; respectively). Administration of strains $E$. faecium CCM8558, $E$. durans ED26E/7, L. fermentum CCM7421 and L. plantarum 17L/1 resulted in a significant larval count reduction with a higher efficacy on day 25 p.i. $(13,220-23,250$ larvae/mice $)$.

\section{Ex vivo fecundity test}

In our experiments, female fecundity was significantly decreased after the administration of enterococci and lactobacilli in comparison to $T$. spiralis infected group without treatment (Fig. 1). The greatest inhibition in female reproductive capacity was caused by strains E. faecium CCM8558 and E. durans ED26E/7 with $94 \%$ reduction of NBL. Similarly, the high reduction of female fecundity was recorded after treatment with $L$. fermentum CCM7421 and L. plantarum 17L/1 (78 \% and $83 \%$ ). The application of strains E. faecium EF55 and E. faecium CCM7420 had only a modest inhibitory effect on the fecundity of females.

In vitro fecundity test

The strain concentration of $10^{7} \mathrm{CFU} / \mathrm{ml}$ was the most effective among four examined concentrations of probiotic strains (Table 3 ). The highest decrease in the number of NBL was recorded after incubation of females with L. fermentum CCM7421 (93 \%) followed by E. faecium CCM8558 (79 \%), L. plantarum 17L/1 (78 \%), E. faecium EF55 (76 \%), E. faecium CCM7420 (62 \%) and finally E. durans ED26E/7, which showed the $60 \%$ reduction. The production of NBL was increased in relation to a decreasing concentration of bacteria. All tested probiotic strains at a concentration of $10^{5} \mathrm{CFU} / \mathrm{ml}$, except of $L$. plantarum $17 \mathrm{~L} / 1$, had a significant inhibitory effect on female fecundity (in the range of $41-72 \%$ ). The females incubated with $E$. faecium CCM8558 or L. fermentum CCM7421 at a concentration of $10^{3} \mathrm{CFU} / \mathrm{ml}$ were $60 \%$ less fecund then control females. In comparison to the control, the lowest con- 
centration of probiotic bacteria $\left(10^{1} \mathrm{CFU} / \mathrm{ml}\right)$ was also efficient to decrease the number of NBL.

\section{Discussion}

The available chemotherapy (benzimidazoles) of human trichinellosis is effective only against adult worms, not against muscle larvae. For trichinellosis as an important parasitic zoonosis with a worldwide distribution and epidemic occurrence (Devleesschauwer et al., 2015), the development of new methods to control this disease is inevitable and the use of probiotic bacteria could be successfully employed (Martínez-Gómez et al., 2011; El Temsahy et al., 2015).

The nematode $T$. spiralis has been chosen as a model parasite to verify anti-parasitic properties of probiotic and bacteriocin-producing strains. Pathogenicity of $T$. spiralis is higher than other intestinal parasites due to the high production of NBL (Pozio et al., 1992) and a strong immune response of the host (Pozio et al., 1993; Bruschi et al., 1999; Morales et al., 2002). This study investigated the influence of tested probiotic bacteria on the adult worm and larvae burdens in mice.

$T$. spiralis infection affects the host in two phases, intestinal and muscular (Abou Rayia et al., 2017). Parasite adults live in the epithelium of the small intestine, where the viviparous females produce a large number of NBL (500 - 1,500 larvae/female) from day 5 p.i. (Mitreva and Jasmer, 2006). These NBL migrate into the blood stream via intestinal lymphatics or mesenteric vessels, and finally reach the striated muscles that represent their predilection sites. There, they induce the formation of nurse cell and become encysted (Despommier, 1983). Gut microflora plays a crucial role in completing the life cycle of the parasite in the intestine, enabling the development into adults and their reproduction, and also in modulating the host immune response. Probiotic bacteria can provide an indirect protection, probably by modulating effect on newborn and muscle T. spiralis larvae (Travers et al., 2011; Dvorožňáková et al. 2016).

Probiotic organisms are able to modulate their physicochemical environment: nutrients, $\mathrm{pH}$, availability of receptors on epithelial cells, the epithelial tight junctions, and peristalsis. Probiotic bacteria can also control their biotic environment by regulating intestinal motility and mucus secretion (Gupta and Garg, 2009; Travers et al., 2011), two major components of the intestinal physiology participating in the host defence against worms (Khan, 2008). The attachment of probiotics to the gut epithelium is an important determinant to achieve their beneficial effect on the host organism. All administered strains from our study sufficiently colonize the small intestine during the infection (Dvorožňáková et al., 2014). In the present study, three strains of enterococci, E. faecium CCM8558, E. faecium CCM7420 and E. durans ED26E/7, significantly reduced the number of adult parasites in the intestine on day 11 p.i., with reduction rates of $53 \%, 51 \%$, and $38 \%$, respectively. On the other hand, L. fermentum CCM7421 and L. plantarum 17L/1 had no influence on worm burden during the intestinal phase of the infection. We assume that it could be caused by the worse adhesive capacity of lactobacilli compared with enterococci (Lauková et al., 2004). A weak anti-adult effect of Lactobacillus strains documented in our experiment is opposite to other studies. After intraperitoneal application of $L$. casei ATCC7469, Bautista-Garfias et al. (1999) recorded $88.5 \%$ reduction in the number of $T$. spiralis adults. Also, when the same $L$. casei strain was administered per os, the reduction effect was $58 \%$ (Bautista-Garfias et al., 2001). Similarly, intraperitoneally applied strain of $L$. casei Shirota implied a $78.6 \%$ reduction of intestinal parasites (Martínez-Gómez et al., 2011). El Temsahy et al. (2015) recorded the reduction of $T$. spiralis adults after treatment with L. plantarum $\mathrm{P} 16456$ by $98 \%$, $65.4 \%$ and $69 \%$ on days 5,12 , and 17 p.i., respectively. These differences between the present study and other studies could result from using of various strains of lactobacilli, different infective and therapeutic doses, application method and/or design of experimental studies. We observed an increase in larval burden between days 25 and 32 p.i. in all experimental groups, untreated or treated mice. This might be caused by the continuous larval migration to the muscles. The increase was the lowest in untreated mice (4,000 larvae/mouse), and similar (5,000 - 10,000 larvae/mouse) in all four treated groups. Only in mice treated with L. plantarum 17L/1 and E. faecium CCM7420 - the numbers of muscle larvae increased by $17,000-19,000$ larvae/mouse, respectively. We can assume that probiotic therapy delayed migration of the NBL and larval motility was disrupted. Bacterial strains produce lactic and acetic acid, hydrogen peroxide, proteinaceous enterocins and bacteriocins, which are important mechanisms in pathogens exclusion (Šušković et al., 2010; Lauková et al., 2012). These bacterial substances might also affect the larvae vitality and participate in their destruction, particularly through hydrogen peroxide. It could be documented by the reduced larval burden. In our study, the number of muscle larvae in treated mice has significantly decreased on days 25 and 32 p.i., particularly in mice with administration of $L$. fermentum CCM7421, L. plantarum 17L/1, $E$. faecium CCM8558, and $E$. durans ED26E/7. The percentage of larval count reduction on day 25 was as follows: $63 \%, 69 \%, 74 \%$, and $54 \%$, respectively. Lower reduction values, yet still significant, were recorded on day 32 p.i.: $51 \%, 41 \%, 56 \%$, and $46 \%$, respectively. Similar efficacy against $T$. spiralis larvae was also shown in another probiotic strains, e.g. L. casei ATCC7469, L. casei Shirota, and $L$. plantarum P164 in a variety of experiments (Bautista-Garfias et al., 2001; Martínez-Gómez et al., 2011; El Temsahy et al., 2015). In this context, it is important to emphasize that the beneficial effects of probiotics cannot be generalized given that they are strain-specific (Gupta and Garg, 2009).

The parasite infectivity is a result of the interplay of four components: the number of females that develop into adults, their fecundity, the length of their survival in the gut, and the period during which the muscle larvae remain viable (Dvorožňáková et al., 2011). The decreased numbers of $T$. spiralis muscle larvae 
induced by bacterial strains in our study might be associated with a reduced female fecundity or destroying of NBL during their migration to the host muscles.

This is the first study that investigates the effect of probiotic strains on the fecundity of $T$. spiralis females. Our aim was to determine whether the reduced parasite burden is associated with a decreased fecundity induced by probiotic strains, or these strains prevented the NBL migration into the blood and the lymphatic circulation, or stimulated host immunity participated on this reduction. It could be discerned by results of ex vivo fecundity test at females isolated from the gut of infected and treated mice. The female reproductive capacity was significantly inhibited after administration of strains E. faecium CCM8558, E. durans ED26E/7 (about 94 \%), L. fermentum CCM7421 and L. plantarum 17L/1 (about $80 \%$ ). In contrast to non-affected numbers of adults presented in the gut of mice treated with Lactobacillus strains, their reproductive capacity was suppressed. These strains did not affect the maturation of $T$. spiralis larvae into adults or their expulsion from the gut, but they contributed to the decreased muscle parasite loads in the host by the control of NBL production.

In vitro test regarding the fecundity of females ex vivo showed the extreme reduction in their reproductive potential. However, it may not reflect the fecundity in vivo where total muscle larval recovery lead to the lower reduction effects what was caused by probiotic therapy. Considering the numbers of larvae, which reached and encysted in muscles, the actual reproduction of females in vivo finished at about $50 \%$. These differences between in vivo and ex vivo female fecundity could be caused by biochemical and physiological conditions within the host organism. For example, the physico-chemical conditions of the jejunum are more fecund than those in the ileum. This site is more appropriate and results in a higher reproductive success of $T$. spiralis (Sukhdeo, 1991). Other authors (Gagliardo et al., 2002) confirmed that the intestinal life cycle of $T$. spiralis (including reproduction) is supported entirely by the host epithelial cells. All these supporting mechanisms provided by the host are absent under in vitro conditions. Based on our results, the impact of our six probiotic strains on female fecundity was elucidated; however, an influence of other factors within the host organism such as gut physiology or immunomodulatory activity of probiotic bacteria cannot be excluded. It could be related to the colonization of the intestinal epithelium with probiotic strains. The adhesion of strains on gut mucosal surfaces and also the production of antibacterial agents as bacteriocins, hydrogen peroxide (Pridmore et al., 2008; Gupta and Garg, 2009; Hertzberger et al., 2014) might prevent the parasite to enter the host epithelial cells, a site where $T$. spiralis larvae molt, ecdyse, develop to adulthood and reproduce (Gagliardo et al., 2002).

Nevertheless, the data obtained from in vitro fecundity test also revealed a direct inhibitory impact of probiotic bacterial strains on female fecundity. The highest efficacy was detected after incubation of $T$. spiralis females with L. fermentum CCM7421 (93\% reduction of NBL) followed by strains E. faecium CCM8558, L. plantarum
17L/1, E. faecium EF55 (about $80 \%$ ), E. faecium CCM7420 and E. durans ED26E/7 (about $60 \%$ ). This may be related to the fact that the genera Lactobacillus and Enterococcus belong to the lactic acid bacteria, which in the process of glucose fermentation produce primarily lactic acid but also other organic acids, e.g. acetate and butyrate (Lauková et al., 1998; Araújo and Ferreira, 2013; Azat et al., 2016). These acids can decrease the local intestinal pH and thus directly disrupt the growth of the acid-sensitive organisms, including parasites (Mukhopadhyay and Ganguly, 2014). Results of the study of El Temsahy (2001) revealed that the acidic gastric $\mathrm{pH}$ led to a significant decrease in the fecundity of $T$. spiralis females both in vivo and in vitro. This was obvious by observing the inability of females to give birth to NBL and morphological changes of the reproductive organs, mainly the uterus, which could cause of the impairment in embryogenesis.

The resistance to $T$. spiralis infection is related to the ability of the host to prevent the development of infective larvae by removing adult worms from the small intestine, limiting the fecundity of adult females, and destroying NBL (Vasconi et al., 2015). Our study confirmed the anti-parasitic effect of six selected probiotic strains using an accelerated kinetics of worm expulsion from the gut (E. faecium CCM8558, E. faecium CCM7420 and E. durans $\mathrm{ED} 26 \mathrm{E} / 7$ ), the reduction in female's reproductive capacity (all examined strains), and by reduction of muscle larvae ( $L$. fermentum CCM7421, L. plantarum 17L/1, E. faecium CCM8558 and E. durans ED26E/7). All these anti-parasitic mechanisms were strain-dependent and were not acting solely, but in cooperation with other host defence mechanisms. This idea has been confirmed by differences in obtained results in anti-parasitic parameters, where decreased presence of adult worms in the gut has not resulted in decreased numbers of muscle larvae and vice versa. The inhibited female fecundity played an important role in infected mice treated with $E$. faecium CCM8558 and E. durans ED26E/7. However, in vitro conditions revealed a strong effect against NBL production in strains L. fermentum CCM7421, L. plantarum 17L/1, E. faecium CCM8558, and E. faecium EF55. This effect was suppressed in the host environment by interactions between bacterial strains, host immune response, and inflammatory processes. Immune mechanisms involved in killing of the NBL include oxidative processes, eosinophil major basic protein or complement activation (Wang, 1997). Mast cells, eosinophils, neutrophils and macrophages are all able to adhere to the larvae surface and destroy NBL during in vitro incubation (Mackenzie et al., 1981). Probiotic strains tested in this study modulated the immune response and stimulated phagocytosis and oxidative burst of blood leukocytes thus participating in the killing of larvae (Dvorožňáková et al., 2016).

Therapeutic approaches with the use of probiotic strains could help to reduce the risks of trichinellosis or complement classical anti-parasite treatments. Our study demonstrates that probiotic bacteria can provide strain-specific protection against $T$. spiralis nematode throughout reduced female fecundity. Several addi- 
tional mechanisms involved in the anti-parasite defence should be further studied and elucidated to justify the therapeutic use of probiotics.

\section{Conflict of Interest}

The authors declare there is no conflict of interest relating to the information presented in this manuscript.

\section{Acknowledgements}

This study was supported by the Slovak VEGA agency, grant No. 2/0081/15.

\section{References}

Abou Rayia, D.M., SaAd, A.E., Ashour, D.S., Oreiby, R.M. (2017): Implication of artemisinin nematocidal activity on experimental trichinellosis: In vitro and in vivo studies. Parasitol. Int., 66(2): 56 63. DOI: 10.1016/j.parint.2016.11.012

Alak, J.I., Wolf, B.W., Mdurvwa, E.G., Pimentel-Smith, G.E., Kolavala, S., Abdelrahman, H., Suppiramaniam, V. (1999): Supplementation with Lactobacillus reuteri or Lactobacillus acidophilus reduced intestinal shedding of Cryptosporidium parvum oocysts in immunodeficient C57BL/6 mice. Cell. Mol. Biol. (Noisy-le-grand), 45(6): $855-863$

Araúso, T.F., Ferreira, C.L.L.F. (2013): The genus Enterococcus as probiotic: safety concerns. Braz. Arch. Biol. Technol., 56(3): 457 - 466. DOI: 10.1590/S1516-89132013000300014

Attia, R.A., Mahmoud, A.E., Farrag, H.M., Makboul, R., Mohamed, M.E., IBRAHEIM, Z. (2015): Effect of myrrh and thyme on Trichinella spiralis enteral and parenteral phases with inducible nitric oxide expression in mice. Mem. Inst. Oswaldo Cruz, 110(8): 1035 1041. DOI: 10.1590/0074-02760150295

Azat, R., Liu, Y., Li, W., Kayir, A., Lin, D., Zhou, W., Zheng, X. (2016): Probiotic properties of lactic acid bacteria isolated from traditionally fermented Xinjiang cheese. J. Zhejiang Univ. Sci. B., 17(8): 597 - 609. DOI: 10.1631/jzus.B1500250

Bautista-Garfias, C.R., Ixta, O., Orduña, M., Martínez, F., Aguilar, B., CORTÉs, A. (1999): Enhancement of resistance in mice treated with Lactobacillus casei: Effect on Trichinella spiralis infection. Vet. Parasitol., 80(3): 251 - 260. DOI: 10.1016/S0304-4017(98)002106

Bautista-Garfias, C.R., Ixta-Rodriguez, O., Martínez-Gómez, F., Lopez, M.G., Aguilar-FigueroA, B.R. (2001): Effect of viable or dead Lactobacillus casei organisms administered orally to mice on resistance against Trichinella spiralis infection. Parasite, 8(Suppl.2): 226 - 228. DOI: 10.1051/parasite/200108s2226

Bautista-Garfias, C.R., Gómez, M.B., Aguilar, B.R., Ixta, O., MartínEZ, F., MosquedA, J. (2005): The treatment of mice with Lactobacillus casei induces protection against Babesia microti infection. Parasitol. Res., 97(6): 472 - 477. DOI: 10.1007/s00436-005-1475-7
Basualdo, J., Sparo, M., Chiodo, P., Ciarmela, M., Minvielle, M. (2007): Oral treatment with a potential probiotic (Enterococcus faecalis CECT7121) appears to reduce the parasite burden of mice infected with Toxocara canis. Ann. Trop. Med. Parasit., 101(6): 559 - 562. DOI: 10.1179/136485907X193824

Berrilli, F., Di Cave, D., Cavallero, S., D'amelio, S. (2012): Interactions between parasites and microbial communities in the human gut. Front. Cell. Infect. Microbiol., 2(Article 141): 1 - 6. DOI: 10.3389/fcimb.2012.00141

Bruschi, F., Pozio, E., Watanabe, N., Gomez-Morales, M.A., Ito, M., HuANG, Y., BINAGHI, R. (1999): Anaphylactic response to parasite antigens: IgE and IgG1 independently induce death in Trichinella-infected mice. Int. Arch. Allergy Immunol., 119(4): 291 - 296. DOI: $10.1159 / 000024206$

BRUSCH, F., ChIUMiento, L. (2012): Immunomodulation in trichinellosis: does Trichinella really escape the host immune system? Endocr. Metab. Immune Disord. Drug Targets, 12(1): 4 - 15. DOI: 10.2174/187153012799279081

CABAJ, W. (1990): The effect of cyclosporine A on the course of infection by Trichinella pseudospiralis or Nematospiroides dubius on C3H strain mice. Acta Parasitol. Pol., 35(3): 241 - 253

Despommier, D. D. (1983): Biology. In: Campbell, W. C. (Ed.) Trichinella and Trichinosis.. London, UK: Plenum Press, pp. 75 - 151. DOI: 10.1007/978-1-4613-3578-8

Devleesschaumer, B., Praet, N., Speybroeck, N., Torgerson, P.R., Haagsma, J.A., De Smet, K., Murrell, K.D., Pozio, E., Dorny, P. (2015): The low global burden of trichinellosis: evidence and implications. Int. J. Parasitol., 45(2 - 3): 95 - 99. DOI: 10.1016/j. ijpara.2014.05.006

DvorožŇ́́KovÁ, E., HuRníKovÁ, Z., KoŁodZIEJ-SobocińSKA, M. (2011): Development of cellular immune response of mice to infection with low doses of Trichinella spiralis, Trichinella britovi and Trichinella pseudospiralis larvae. Parasitol. Res., 108(1): 169 - 176. DOI: 10.1007/s00436-010-2049-x

Dvorožñáková, E., Hurníková, Z., Revajová, V., Lauková, A. (2014): Effects of bacteriocinogenic and probiotic bacteria on cellular immunity and parasite (Trichinella spiralis) infection in mice. In ICOPA XIII: 13 International congress of parasitology, August 10-15, 2014. Mexico, no. 1135 , p. 109

Dvorožñáková, E., Bucková, B., Hurníková, Z., Revajová, V., LauKoVÁ, A. (2016): Effect of probiotic bacteria on phagocytosis and respiratory burst activity of blood polymorphonuclear leukocytes (PMNL) in mice infected with Trichinella spiralis. Vet. Parasitol., 231(2016): 69 - 76. DOI: 10.1016/j.vetpar.2016.07.004

EL Temsahy, M.M. (2001): The effect of changes in the gastric pH value on experimental trichinosis. J. Egypt. Soc. Parasitol., 31(3): $671-682$

El Temsahy, M.M., Ibrahim, I.R., Mossallam, S.F., Mahrous, H., Abdel Bary, A., Abdel Salam, S.A. (2015): Evaluation of newly isolated probiotics in the protection against experimental intestinal trichinellosis. Vet. Parasitol., 214(3 - 4): 303 - 314. DOI: 10.1016/j. vetpar.2015.08.029 
Eze, J.I., Orajaka, L.J., Okonkwo, N.C., Ezeh, I.O., Ezema, C., Anosa, G.N. (2012): Effect of probiotic (Saccharomyces cerevisiae) supplementation on immune response in Trypanosoma brucei brucei infected rats. Exp. Parasitol., 132(4): 434 - 439. DOI: 10.1016/j. exppara.2012.09.021

Gagliardo L.F., Mcvay C.S., Appleton J.A. (2002): Molting, ecdysis, and reproduction of Trichinella spiralis are supported in vitro by intestinal epithelial cells. Infect. Immun., 70(4):1853 - 1859. DOI: $10.1128 / I A I .70 .4 .1853-1859.2002$

Galdeano, C.M., Perdigón, G. (2006): The probiotic bacterium Lactobacillus casei induces activation of the gut mucosal immune system through innate immunity. Clin. Vaccine Immunol., 13(2): 219 - 226. DOI: 10.1128/CVI.13.2.219-226.2006

GARGALA, G. (2008): Drug treatment and novel drug target against Cryptosporidium. Parasite, 15(3): 275 - 281. DOI: 10.1051/parasite/2008153275

Goudarzi, M., Goudarzi, H., Rashidan, M. (2014): Probiotics: an update on mechanisms of action and clinical applications. Novel. Biomed., 2(1): 22 - 30

Goździk, K., Odoevskaya, I.M., Movsesyan, S.O., Cabas, W. (2017): Molecular identification of Trichinella isolates from wildlife animals of the Russian Arctic territories. Helminthologia, 54(1): 11 - 16. DOI: 10.1515/helm-2017-0002

GuptA, V., GARG, R. (2009): Probiotics. Indian J. Med. Microbiol., 27(3): 202 - 209. DOI: 10.4103/0255-0857.53201

Hertzberger, R., Arents, J., Dekker, H.L., Pridmore, R.D., Gysler, C., Kleerebezem, M., De Mattos, M.J. (2014): $\mathrm{H}_{2} \mathrm{O}_{2}$ production in species of the Lactobacillus acidophilus group: a central role for a novel NADH-dependent flavin reductase. Appl. Environ. Microbiol., 80(7): 2229 - 2239. DOI: 10.1128/AEM.04272-13

Kapel, C.M.O., Gamble, H.R. (2000): Infectivity, persistence, and antibody response to domestic and sylvatic Trichinella spp. in experimentally infected pigs. Int. J. Parasitol., 30(2): 215 - 221. DOI: 10.1016/S0020-7519(99)00202-7

KHAN W.I. (2008): Physiological changes in the gastrointestinal tract and host protective immunity: learning from the mouse-Trichinella spiralis model. Parasitology, 135(6):671 - 682. DOI: 10.1017 | S0031182008004381

Lauková, A., CZikková, S., Vasilková, Z., Juriš, P., Mareková, M. (1998): Occurrence of bacteriocin production among environmental enterococci. Lett. Appl. Microbiol., 27(3): 178 - 182. DOI: 10.1046/j.1472-765X.1998.00404.x

Lauková, A., Strompfová, V., Ouwehand, A. (2004): Adhesion properties of enterococci to intestinal mucus of different hosts. Vet. Res. Commun., 28(8): 647 - 655. DOI: 10.1023/B:VERC.0000045948.04027.a7

Lauková, A., Chrastinová, L'., Pogány Simonová, M., Strompfová, V., Plachá, I., Čobanová, K., Formelová, Z., Chrenková, M., OndrušKa, L. (2012): Enterococcus faecium AL41: its enterocin M and their beneficial use in rabbits husbandry. Probiotics Antimicrob. Proteins, 4(4): 243 - 249. DOI: 10.1007/s12602-012-9118-7

Lauková, A., Szabóová, R., Strompfová, V., KmeŤ, V., Tomáška, M.,
GreifovÁ, M., GreIF, G. (2013): Bacteriocin-like active strain Lactobacillus plantarum 17L/1, isolate from stored sheep cheese. Abstracts of International Scientific Conference Hygiena alimentorum XXXIV, May 8-10, 2013. Štrbské pleso, The Slovak Republic. In Folia Vet., 57(Suppl.1), p. 21

Lauková, A., Chrastinová, L'., KandričÁková, A., Ščerbová, J., Plachá, I., Pogány Simonová, M., Čobanová, K., Formelová, Z., OndrušKa, L', StromprovÁ, V. (2015): Bakteriocínová substancia duracín-like ED26E/7 a jej experimentálne využitie v chove brojlerových králikov [Bacteriocin substance durancin-like ED26E/7 and its experimental use in broiler rabbits husbandry]. Maso, 2015(5): 56 - 59 LI, R.W., Wu, S., LI, W., Navarro, K., Couch, R.D., Hill, D., URban, J.F. JR. (2012): Alterations in the porcine colon microbiota induced by the gastrointestinal nematode Trichuris suis. Infect. Immun., 80(6): 2150 - 2157. DOI: 10.1128/IAI.00141-12

Mackenzie, C.D., Jungery, M., Taylor, P.M., Ogilvie, B.M. (1981): The in vitro interaction of eosinophils, neutrophils, macrophages and mast cells with nematode surfaces in the presence of complement or antibodies. J. Pathol., 133(2): 161-175. DOI: 10.1002/ path. 1711330207

Mareková, M., Lauková, A., Skaugen, M., Nes, I. (2007): Isolation and characterization of a new bacteriocin, termed enterocin $M$, produced by environmental isolate Enterococcus faecium AL41. J. Ind. Microbiol. Biotechnol., 34(8): 533 - 537. DOI: 10.1007/ s10295-007-0226-4

Martínez-Gómez, F., Ixta-Rodriguez, O., Aguilar-Figueroa, B., Hernández-Cruz, R., Monroy-Ostria, A. (2006): Lactobacillus casei ssp. rhamnosus enhances nonspecific protection against Plasmodium chabaudi AS in mice. Salud Publica Mex., 48(6): 498 - 503. DOI: 10.1590/S0036-36342006000600008

Martínez-Gómez, F., Santiago-Rosales, R., Ramón Bautista-Garfias, C.R. (2009): Effect of Lactobacillus casei Shirota strain intraperitoneal administration in CD1 mice on the establishment of Trichinella spiralis adult worms and on IgA anti-T. spiralis production. Vet. Parasitol., 162(1 - 2): 171 - 175. DOI: 10.1016/j.vetpar.2009.02.010 Martínez-Gómez, F., Fuentes-Castro, B.E., Bautista-Garfias, C.R. (2011): The intraperitoneal inoculation of Lactobacillus casei in mice induces total protection against Trichinella spiralis infection. Parasitol. Res., 109(6): 1609 - 1617. DOI: 10.1007/s00436-0112432-2

Mitreva, M., JAsmer, D.P. (2006): Biology and genome of Trichinella spiralis. In: WormBook: The online review of C. elegans biology. Retrieved November, 2017 from https://www.ncbi.nlm.nih.gov/ books/NBK19691. DOI: 10.1895/wormbook.1.124.1

Morales, M.A.G., Mele, R., Sanchez, M., Sacchini, D., De Giacomo, M., Pozıo, E. (2002): Increased CD8(+)-T-cell expression and a type 2 cytokine pattern during the muscular phase of Trichinella infection in humans. Infect. Immun., 70(1): 233 - 239. DOI: 10.1128/ IAI.70.1.233-239.2002

Mukhopadhyay, B., Ganguly, N.K. (2014): The unexplored role of probiotics on the parasitic pathogens. Food Nutr. Sci., 5(22): 2177 - 2184. DOI: $10.4236 /$ fns.2014.522230 
Othman, A.A., Shoheib, Z.S. (2016): Detrimental effects of geldanamycin on adults and larvae of Trichinella spiralis. Helminthologia, 53(2): 126 - 132. DOI: 10.1515/helmin-2016-0003

Pérez, P.F., Minnaard, J., Rouvet, M., Knabenhans, Ch., Brassart, D., De AntonI, G.L., Schiffrin, E.J. (2001): Inhibition of Giardia intestinalis by extracellular factors from Lactobacilli: an in vitro study. Appl. Environ. Microbiol., 67(11): 5037 - 5042. DOI: 10.1128/ AEM.67.11.5037-5042.2001

PISKORíKovÁ, M. (2010): Quality and characterization of existing and new probiotics (EFSA QPS). In Proceedings of Regulatory Framework Workshop Health Claim Approval of Probiotics in the European Union Issusses, 18. June, 2010. Košice, The Slovak Republic.

Pogány Simonová, M., Lauková, A., Plachá, l., Čobanová, K., Strompfová, V., Szabóová, R., Chrastinová, L'. (2013): Can enterocins affect phagocytosis and glutathione-peroxidase in rabbits? Cent. Eur. J. Biol., 8(8): 730 - 734. DOI: 10.2478/s11535-013-0198-x.

Pozio, E., La Rosa, G., Murrell, K.D., Lichtenfels, J.R. (1992): Taxonomic revision of the genus Trichinella. J. Parasitol., 78(4): 654 - 659. DOI: $10.2307 / 3283540$.

Pozio, E., Varese, P., Morales, M.A., Croppo, G.P., Pellicia, D., BRUSCH, F. (1993): Comparison of human trichinellosis caused by Trichinella spiralis and by Trichinella britovi. Am. J. Trop. Med. Hyg., 48(4): 568 - 575. DOI: 10.4269/ajtmh.1993.48.568.

Pridmore, R.D., Pittet, A.C., Praplan, F., Cavadini, C. (2008): Hydrogen peroxide production by Lactobacillus johnsonii NCC 533 and its role in anti-Salmonella activity. FEMS Microbiol. Lett., 283(2): 210 - 215. DOI: 10.1111/j.1574-6968.2008.01176.x

SHUKLA, G., SIDHU, R.K. (2011): Lactobacillus casei as a probiotic in malnourished Giardia lamblia-infected mice: a biochemical and histopathological study. Can. J. Microbiol., 57(2): 127 - 135. DOI: 10.1139/w10-110

Solano-Aguilar, G., Shea-Donohue, T., Madden, K., Dawson, H., Ledbetter, T., Urban, J.J. (2004): The effect of human-derived probiotic bacteria on the intestinal function of pigs. Vet. Parasitol., 125(1): 147 - 161

Strompfová, V., Marciñáková, M., Simonová, M., Lauková, A., FialkovıčovÁ, M. (2008): Probiotic strain Lactobacillus fermentum CCM 7421 , canine isolate applied to dogs suffering from gastrointestinal disorders. Int. J. Probiotics Prebiotics, 2(4): $233-238$

Strompfová, V., Lauková, A., MarciñákOVÁ, M., VasilKovÁ, Z. (2010): Testing of probiotic and bacteriocin-producing lactic acid bacteria towards Eimeria sp. Pol. J. Vet. Sci., 13(2): 389 - 391

SUKHDEO M. V. K. (1991): The relationship between intestinal location and fecundity in adult Trichinella spiralis. Int. J. Parasitol., 21(7): 855-858. DOI: 10.1016/0020-7519(91)90154-Y

Šušković, J., Kos, B., Beganović, J., Leboš Pavunc, A., Habjanič, K., Matošı́, S. (2010): Antimicrobial Activity - The Most Important Property of Probiotic and Starter Lactic Acid Bacteria. Food Technol. Biotech., 48(3): $296-307$

Travers, M.A., Florent, I., Kohl, L., Grellier, P. (2011): Probiotics for the control of parasites: an overview. J. Parasitol. Res., 2011 (610769). DOI: 10.1155/2011/610769

Vasconi, M.D., Bertorini, G., Codina, A.V., Indelman, P., Di Masso, R.J., HINRICHSEN, L.I. (2015): Phenotypic characterization of the response to infection with Trichinella spiralis in genetically defined mouse lines of the CBi-IGE Stock. Open J. Vet. Med., 5(5): 111 - 122. DOI:10.4236/ojvm.2015.55015

Walk, S.T., Blum, A.M., Ewing, S.A., Weinstock, J.V., Young, V.B. (2010): Alteration of the murine gut microbiota during infection with the parasitic helminth Heligmosomoides polygyrus. Inflamm. Bowel Dis., 16(11): 1841 - 1849. DOI: 10.1002/ibd.21299

WANG, C.H. (1997): Study of biological properties of Trichinella spiralis newborn larvae and the antiparasitic mucosalimmunity of the host. Front. Biosci., 2:d317-30.Yadav, A.K., Temuenmongla (2012): Efficacy of Lasia spinosa leaf extract in treating mice infected with Trichinella spiralis. Parasitol. Res., 110(1): 493 - 498. DOI: 10.1007/s00436-011-2551-9 